\title{
Kody odmienności kulturowej w literaturze szwedzkiej i jej przekładach. Na przykładzie Trylogii sztokholmskiej Jensa Lapidusa
}

\author{
Magdalena Wasilewska-Chmura \\ Uniwersytet Jagielloński w Krakowie \\ magdalena.wasilewska-chmura@uj.edu.pl
}

Streszczenie

Artykut podejmuje temat językowych reprezentacji kulturowej odmienności $w$ literaturze szwedzkiej, przedstawiajacej środowiska imigranckie i/lub rozwarstwione klasowo. Język, zarówno protagonistów jak i narracji, jest konstruktem literackim, który eksponuje jedynie niektóre elementy językowe (glównie leksykalne) jako relewantne dla osiagnięcia pragmatycznego celu - efektu obcości. Przedmiotem artykułu jest analiza stylistyczna zastosowanych środków oraz strategie ttumaczy zmierzajace do uzyskania ekwiwalencji funkcjonalnej.

Słowa kluczowe: przekład literacki, stylizacja, potoczność

Abstract

Indications of cultural otherness in Swedish literature and its translations. Exemplified by Stockholm Trilogy by Jens Lapidus

The article takes up the problem of linguistic representations of cultural otherness in Swedish literature featuring immigrant and/or class-stratified environments. The language, both of the protagonists as well as the narration, is a literary construct exposing only those linguistic elements (mainly lexical ones) which are relevant for achieving a pragmatic purpose - the effect of otherness. The article presents a stylistic analysis of the means of expression employed together with translators' strategies aimed at achieving a functional equivalence.

Keywords: literary translation, stylization, colloquial style 
Studia postkolonialne obnażyły imperialną politykę kulturową Zachodu wobec tzw. Orientu, która traktowała Obcego jako prymitywną jednostkę, wymagającą europejskiej misji cywilizacyjnej (Said [1978] 1991: 28). Od czasów kolonialnych zmieniła się topografia obcości: to już nie Europejczyk wkracza na obce terytoria, narzucając im swoje kulturowe normy, lecz fale migracji przybywają do Europy, gdzie stają wobec kultury par excellence dominującej. Pojawia się pytanie, jak globalnym świecie zmienił się obraz Obcego. Literatura szwedzka dostarcza w tym względzie sporo materiału, bowiem społeczeństwo jest od co najmniej pół wieku oswojone z liczną imigracją i problemami wielokulturowości. Na rynku literackim funkcjonuje grupa pisarzy o imigranckich korzeniach, którzy często tematyzują problem tożsamości z perspektywy kulturowych peryferii wobec centrum, zgodnie z ujęciem postkolonialnym. W niniejszym tekście analizuję jednak sytuację odwrotną: literackie reprezentacje odmienności kulturowej środowisk imigranckich w cyklu powieści kryminalnych szwedzkiego pisarza, Jensa Lapidusa.

Punktem wyjścia jest tu tekst literacki jako konstrukt językowy, który rządzi się konwencjami gatunkowymi i stylistycznymi. Języki, żargony i style komunikacyjne w literaturze nie są wszak realistyczne w sensie odwzorowania rzeczywistości, lecz są literackimi reprezentacjami, a zatem podlegają określonym konwencjom. Nadrzędną kategorią jest bowiem styl literacki, w ramach którego można stosować rozmaite zabiegi stylizacyjne, mając na celu wywołanie określonego efektu.

Pojęcie stylizacji odnosi się, według Balbusa ([1996] 2006: 20), do „takiej wypowiedzi literackiej, której zasadą konstrukcyjną jest podrobienie cudzego stylu, tj. stylu funkcjonującego w świadomości społecznej jak ‘czyjaś własność’”. Dla zaistnienia stylizacji niezbędne jest napięcie między wzorcem stylistycznym a terenem stylizacji. Może się ono przejawiać w samym tekście jako jego stylistyczna niejednorodność albo w sytuacji komunikacyjnej, kiedy autorska rama modalna nadaje wypowiedzi cudzysłowowy charakter, a jej stylistyczny kształt nabiera cech kreowanej fikcji literackiej (Balbus [1996] 2006: 21). Z perspektywy językoznawczej stylizacja to „znak ikoniczny określonego stylu” (Mayenowa [1974] 2000: 346), co oznacza, że nie wskazuje on na rzeczywistość, lecz jest „wyborem cech, które chcemy uznać za charakterystyczne, jest oceną, której wynikiem jest podkreślenie jednych cech, opuszczenie innych” (Mayenowa [1974] 2000: 348). Wybór ten może mieć różny charakter u różnych autorów, odwołujących się do tego samego typu wypowiedzi, rozumianych jako styl. 
Idąc tym tropem, nie będę się tu zajmować cechami języka sygnalizującymi odrębność kulturową w wielokulturowej rzeczywistości Szwecji, lecz językiem w ramie modalnej literatury, gdzie jest on taką samą kreacją jak świat przedstawiony, postaci, fabuła itp. Nie ograniczam się przy tym do dialogów, choć to one uważane są za naturalny kanał zindywidualizowanej ekspresji języka. Pokażę natomiast, że również narracja może przekazywać - nie tylko w planie treści, ale przez samą swoją językową formę - informację metakulturową. Dopiero na tym tle będę komentować wybory tłumaczy jako funkcjonalnie uwarunkowane na efekt w języku docelowym i od jego norm uzależnione. Analizy mają charakter jakościowy, nie ilościowy, toteż naświetlone będą konteksty konkretnych użyć języka, gdyż dopiero wówczas można mówić o ich funkcjonalności.

Jens Lapidus (ur. 1974) jest autorem bestsellerowych thrillerów, rozgrywających się w przestępczym światku Sztokholmu, którym rządzą etnicznie wyodrębnione grupy przestępcze, powiązane ciemnymi interesami $\mathrm{z}$ kręgami finansjery $\mathrm{i}$ arystokracji szwedzkiej. W jego pierwszym cyklu powieściowym, zwanym Trylogią sztokholmską, stolica Szwecji jawi się jako tygiel rozmaitych kultur, języków, obcych akcentów, przestępczego slangu i grypsery. Podaję skrócone charakterystyki głównych protagonistów, by unaocznić wielokulturowy wymiar świata przedstawionego ( $\mathrm{w}$ nawiasach skróty stosowane $\mathrm{w}$ dalszym ciągu tekstu):

\section{Snabba cash, 2006 (SC) / Szybki cash, 2008 (SzC), thum. Mariusz Kalinowski:}

Jorge - Latynos, po ucieczce z więzienia organizuje wielki przemyt kokainy; JW - Szwed, obraca się w kręgach arystokracji, ukrywając swe pochodzenie, zarabia na nielegalnych interesach na coraz większą skalę; Mrado - Serb, jeden z bossów mafii jugosłowiańskiej.

\section{Aldrig fucka upp, 2008 (AFU) / Zimna stal, 2009 (ZS), thum. Mariusz Kalinowski:}

Mahmud - Arab, po odsiadce w zatargu za mafią jugosłowiańską; Niklas - Szwed, były najemnik, na własną rękę tropi i zabija sprawców przemocy wobec kobiet; Thomas - policjant, zdegradowany za dociekliwość w politycznym śledztwie, dorabia jako ochroniarz dla mafii.

\section{Livet de luxe, 2011 (LDL) / Życie de luxe, 2013 (ŻDL), tlum. Paulina Jankowska:}

Natalie - córka zamordowanego szefa mafii jugosłowańskiej, przejmuje jego imperium; Jorge - po wyjściu z więzienia przeprowadza napad na konwój z pieniędzmi; Hägerström policjant działający pod przykryciem w celu rozpracowania mafijnych interesów. 
Efekt osiąga autor przez stylizację językową na coś, co roboczo nazywam „socjolektem imigranckim". Jest ona stosowana zarówno w dialogach, co wydaje się całkiem naturalne, jak i w narracji, która jest silnie sfokalizowana, tzn. narrator przyjmuje punkt widzenia kilkorga głównych protagonistów o różnej przynależności etnicznej, a co za tym idzie ich system wartości, sposób myślenia i język (,potoczna świadomość”, Warchala 2003: 32). Najbardziej oczywistymi wskaźnikami „nieszwedzkości” są środki leksykalne (Stasiak-Górna 2014: 220), tu: często pojawiające się słowa obcego pochodzenia (tureckiego, arabskiego i hiszpańskiego), np. shunne (facet), aina (tur. policja), guzz, l.mn. guzzar (tur. dziewczyna), nader liczne anglicyzmy (flow, spliff, boys) oraz określenia Szwedów i nie-Szwedów - rzecz jasna, z perspektywy tych drugich. Szwed to zatem svensson lub svenne (od popularnego nazwiska $\mathrm{i}$ imienia), alternatywnie Lasse (od zdrobnienia popularnego imienia Lars). Nie-Szwedzi to blattar - określenie początkowo pejoratywne na osoby o „niearyjskich” cechach wyglądu (wg słowniczka, Lapidus 2008b: 573), z czasem jednak przyjęte przez nich jako element nieszwedzkiej tożsamości, pozostającej w opozycji wobec polityki integracji. W ten sposób zostają zdefiniowane tożsamości etniczne z perspektywy peryferii wobec centrum.

Zacznijmy od dialogu, który - obywając się bez pośrednictwa narratora - wprowadza do języka pisanego odmianę mówioną (Skudrzykowa 1994: 7-8) - często potoczną, nacechowaną środowiskowo (Warchala 2003: 7, 14). Oto jak wygląda rozmowa między dwoma Serbami z tzw. „mafii jugolskiej”:

- Dobra došao, wejdź, Mrado. [...]

Radovan, po serbsku:

- Cała przyjemność po mojej stronie. Nie widujemy się zbyt często. - Mrado wciąż stał.

- Siądźże, na miłość boską. [...]

- Darujmy sobie te grzeczności, Mrado (SzC: 100-101).

Formuła powitania oraz narracja sugerują, że rozmowa toczy się po serbsku - frazy idiomatyczne (podkreślone) wskazują, że jest to język rodzimy protagonistów, zachowujący poprawność i normy kulturowe (grzeczności jako wstęp do rozmowy o interesach). W dalszym ciągu, kiedy boss objaśnia szczegóły działalności - rozmowa przechodzi w ton kolokwialny, nacechowany wulgaryzmami (zob. Grochowski 2001: 19): 
Możliwych jest parę scenariuszy. Pierwszy jest taki, że gliny przycisną tego skina, że nas wyda. A wtedy wdrożą jakieś ochujałe śledztwo, rozpełzną się po wszystkich knajpach, gdzie mamy choć trochę kontroli. [...] Inny scenariusz, że HA, czy Göran Boman, czy ktoś inny, wkurwi się, żeśmy poszli zbyt szeroką ławą na froncie garderobianym (SzC: 102-103).

Serbskie pozdrowienie na początku (por. poprzedni cytat) wydaje się wystarczające dla konsekwentnego odbioru kolokwializmów (podkreślone) i wulgaryzmów (wytłuszczone) jako powiązanych z obcością kulturową. Na dyskurs etniczny nakłada się tu jednak dyskurs klasowy - język imigrantów przybiera cechy języka mieszkańców przedmieść o złej sławie oraz subkultur przestępczych.

Podobnie w rozmowie szwedzkiego bohatera JW z Arabem Abdulkarimem:

- Salam alejkum. Jak tam twoje studia? - Jasny głos Abdulkarima, prawie bez akcentu. JW podniósł wzrok znad wyświetlacza. [...]

- Studia idą świetnie.

[...] Abdulkarim usiadł. Machnął wyciągniętą ręką, żeby zwrócić na siebie uwagę kelnerek. Cały Abdul. Robił nazbyt zamaszyste gesty, w sposób nieszwedzki i bezczelny. (SzC, 156-157)

Jest oczywiste, że rozmowa - poza arabskim pozdrowieniem - toczy się po szwedzku. Natomiast narracja prowadzona z perspektywy Szweda ujmuje postrzeganie odmienności kulturowej Araba w świecie szwedzkich norm zachowań i niewerbalnych kodów. W dalszym ciągu rozmowy dochodzą do głosu również elementy obcości klasowej:

"Riktigt 'schysst' alltså." Abdulkarim härmade. "Jag känner ju din story. Sluta säga ordet schysst som om du bott på Östermalm hela ditt liv" (S.C.: 129).

- No wiesz, wysoka klasa. - Abdul go przedrzeźniał. - Ja znam twoją historię. Przestań mi tu mówić „wysoka klasa”, jakbyś wychował się na Östermalmie (SzC: 157).

Östermalm to bogata dzielnica Sztokholmu, tzw. dobry adres. Szwedzkie słowo schysst, użyte w oryginale, jest pozytywnie nacechowanym atrybutem ['uczciwy', 'w porządku'], od lat 60 . raczej potocznym, który obecnie może mieć - z akcentem sztokholmskim - nieco snobistyczny wydźwięk. Tłumacz rezygnuje więc z dawnych polskich kolokwializmów, lecz wprowadza nieco nadętą frazę „wysoka klasa”, która sugeruje aspiracje społeczne bohatera. W dalszym ciągu rozmowa na temat nielegalnych interesów przechodzi w kolokwialny ton, nasycony slangiem i wulgaryzmami. 
Podobnie w Zimnej stali, w scenie między Mahmudem a członkami mafii serbskiej, gdzie pobrzmiewa zawoalowana groźba:

"Lyssna. [...] Du fixar fram cashen till oss och sluta tjafsa. Hade du inte jiddrat hade vi inte behövt köra det här racet. Capish? (AFU: 9).

- Posłuchaj. [...] Załatwisz nam ten cash i już żadnego chuju-muju. Jak byś nie fikał, to by się odbyło bez tych metod. Kapisz? (ZS: 10).

Jest to stylizacja na język subkultury przestępczej, osiągnięta głównie środkami leksykalnymi: kolokwializmami (fixa fram 'skołować', cash 'kasa', tjafsa 'gadać głupoty'), slangiem (jiddra 'kombinować') i zapożyczeniami; capish pochodzi mianowicie z angloamerykańskiego slangu, a pierwotnie - z języka włoskiej mafii ('capisci'). Te cechy stają się, pośrednio, wyznacznikiem peryferyjnej etniczności . Natomiast niemal brak w dialogach łamanej szwedczyzny, której należałoby się spodziewać w kręgach wieloetnicznych. Występuje ona jedynie jako element kolorytu środowiskowego imigranckich dzielnic, np. w scenie targowania w arabskim sklepiku, której przygląda się Mahmud:

Atmosfären grymt osuedi: en annan värld, ett annat land. [...]

”Tror ni jag är gjord av pengar? Jag max ger hundra för varje." (AFU: 83).

Atmosfera radykalnie nie suedi: inny świat, inny kraj. [...]

- Co wy? Myślicie, że ja sram pieniądze? Ja [*] maksymalnie dla was sto za sztuka (ZS: $100)$.

Błędny szyk zdania szwedzkiego, w którym orzeczenie musi być na drugim miejscu (tu na trzecim - wytłuszczone), jest oczywistym wyznacznikiem słabego opanowania języka. Polski szyk, z racji dużej swobody, nie daje takich możliwości sugerowania obcości, toteż błąd składniowy został oddany przez opuszczenie czasownika (zaznaczone [*]) oraz dwukrotnym użyciem nieodmienionego rzeczownika (podkreślenie), gdyż w polszczyźnie właśnie końcówki fleksyjne stanowią największy problem cudzoziemców.

Równie rzadka jest stylizacja dialogu pod względem fonetycznym, choć przecież to detale wymowy są pierwszym rozpoznaniem tzw. obcego akcentu, nawet jeśli zasady gramatyki zostały bezbłędnie opanowane. Oto jeden z nielicznych przykładów:

”Tjena, brushan!" [...] Läget då brushan? Får du rulla nåt?” Killen säker rasist in i märgen, ändå - hans miljonärssvenska gungade. [...]”Det händer brushan, det händer.” Han uttalade ordet brorsan på samma sätt som Peppe (LDL: 11-12). 
- Siemasz, człowieku! [...] - No, jak tam, ziomuś? Podupczyłeś już sobie? Koleżka, z pewnością rasista do szpiku kości, gadał, jednak nieco łamanym imigranckim slangiem. [...]

- Zdarza się, ziomuś - odpowiedziała Jorge, wymawiając słowo „ziomuś” dokładnie tak jak

Peppe (ŻDL: 14).

W oryginale za sprawą zmiany pisowni kluczowego słowa (brushan zamiast brorsan, konsekwentnie powtarzane) zasugerowano jego błędną artykulację samogłoski [u]. W przekładzie bliżej nieokreślona cecha wymowy została jedynie skomentowana w narracji. Nie wiemy jednak, jak Peppe wymawiał słowo „ziomuś” (które ponadto jest jednym z dwóch zastosowanych ekwiwalentów oryginalnego brushan) i czy jego wymowa ma związek z obcym akcentem, czy też należy do idiolektu.

Jak widać, język dialogów nawet w oryginale powieści nie odtwarza językowej rzeczywistości wielokulturowego społeczeństwa, w której mowa jest zróżnicowana pod względem poprawności gramatycznej, fonetycznej, intonacyjnej, w końcu również frazeologicznej. Tutaj socjolekt imigrancki realizuje się głównie poprzez rejestr stylistyczny: styl mówiony, kolokwialny, silnie nacechowany ekspresyjnie. W ten sposób komunikacja nie zostaje zakłócona; dialog pełni bowiem w powieści zbyt istotne funkcje: zdarzeniotwórczą, charakteryzującą, informacyjną (Markiewicz 1996: 85). Tutaj funkcja charakteryzująca nie przesłania nigdy pozostałych.

Tym bardziej interesująca jest językowa konstrukcja narracji. Narracja w swej tradycyjnej, tj. relacyjnej funkcji występuje sporadycznie i przechodzi płynnie w narrację zindywidualizowaną, która nosi cechy monologowej spontaniczności. Inspiracje stylistyczne czerpał autor z amerykańskiego kryminału spod znaku Jamesa Ellroya, szwedzkiego rapu i prozy imigranckiej Jonasa Hassena Khemiriego.

Oto reakcja Mahmuda zaproszonego jako VIP na mafijną imprezę. Narrację otwiera arabska interiekcja, wyrażająca podziw dla otaczającego go blichtru:

Abbou [...] Mahmud [*] inte snubben som lät sig överrumplas av feta bilar, tjålat bling-bling eller oviktiga flos. Han: killen som rullat fram i en Audi innan det sket sig. Shunnen som becknat preparat för hundra papp i månaden. Muskelberget. Pussypirayan. Miljonärlegenden (AFU: 55).

Abbou [...] Mahmud nie z tych, co tracą głowę na widok wypasionej fury, szpanerskich blingblingów czy harmonii szmalu. On: facet, który jeździł audi, zanim sprawa się jebła. Shunne, który opylał preparatu za sto baniek miesięcznie. Góra mięśni. Pies na lolitki. Legenda Projektu Milion (ZS: 65). 
Oprócz licznych kolokwializmów i wyrażeń slangowych (podkreślone), styl cechuje następstwo krótkich fraz, głównie nominalnych, pełniących funkcję orzecznika, przy jednoczesnym opuszczeniu łącznika, a zatem jednocześnie samodzielnych i silnie powiązanych z podmiotem (Mahmud/On). Wpływa to na tempo narracji oraz stwarza sugestię atomizacji wrażeń i uproszczonego pojmowania rzeczywistości (atrybuty bogactwa, siły i seksu). Znaki interpunkcyjne zastępują bardziej złożone struktury myślowe i językowe, wyrażające relacje przyczynowo-skutkowe. Gdy ich jednak zabraknie, wypowiedzenie staje się błędne pod względem gramatycznym: zdanie główne jest pozbawione orzeczenia (zaznaczone [*]).

W polszczyźnie nieciągłość ta zanika tam, gdzie sam szyk jest nośnikiem informacji stylistycznej. Fraza ,[on] nie z tych, co...” jest w tym kontekście zbyt idiomatyczna i poprawna. Natomiast błędy gramatyczne w strukturach niemających odpowiednika w systemie języka polskiego, często nie znajdują ekwiwalencji w przekładzie:

Tydligen var målet slut - åklagare[-] [*] gett upp att få tag på rånarna (AFU: 83).

Najwyraźniej sprawa była już umorzona - prokurator stracił nadzieję na wykrycie sprawców. (ZS: 99).

Tutaj zdanie szwedzkie pozbawione jest odmiennej części orzeczenia złożonego (hade $\mathrm{w}$ miejscu zaznaczonym [*]), co jest dopuszczalne w zdaniu podrzędnym, ale nie w zdaniu głównym. Jest to jeden z błędów języka imigranckiego który opiera się na frazach zasłyszanych i słowach semantycznie pełnych, bez uwzględnienia funkcji i znaczenia słów gramatycznych. Dodatkowym błędem, który nie uzyskał ekwiwalencji w przekładzie $\mathrm{z}$ racji różnic systemowych, jest brak rodzajnika określonego -n (zob. [-]).

W kolejnym przykładzie zachowany zostaje jednak styl krótkich fraz, niepełnych zdań, jakby ufundowanych na brakującym czasowniku posiłkowym - występują tylko formy supinum. Tym samym zostaje zachowane tempo i nieciągłość narracji:

Det kändes bra. Mahmud [*] fått en ledtråd. Spritt budskapet. Närmat sig (AFU: 86).

To już było coś. Mahmud trafił na ślad. Rozpuścił wieści. Zbliżał się (ZS: 103).

Przykłady z błędną składnią potwierdzają, iż brak orzeczenia w formie osobowej jest w Trylogii sztokholmskiej stylistycznym środkiem reprezentacji niepoprawności, który jednocześnie nie zakłóca procesu komunikacji; ponadto jest używany raczej oszczędnie. We wszystkich 
przypadkach te błędne struktury nie znalazły ekwiwalentu $\mathrm{w}$ przekładzie na poziomie gramatycznym. Natomiast w następnym przykładzie ingerencje tłumacza idą znacznie dalej:

Jorge [*] sovit taskigt i natt. Hela grejen: som Agent Smith mot Neo. Det mörka mot det ljusa. Svennebananlivet: något som tärde. The dark side (LDL: 9).

Kiepsko spał ostatniej nocy. Cała sprawa przypominała starcie agenta Smitha z Neo. Walkę ciemności ze światłem. Uwierało go życie svenne. The dark side (ŻDL: 11).

Tłumaczka 3. tomu wyraźnie zmienia składnię oryginału, nadając narracji spójność gramatyczną i płynność, ale też zupełnie inny rytm. Tego elementu nie rekompensują funkcjonalnie środki leksykalne, charakterystyczne dla stylu potocznego, ani inne środki stylistyczne. Coś zostało utracone w thumaczeniu.

Podsumowując, socjolekt imigrancki oddany jest przez Lapidusa jako stylizacja języka, która w pierwszym rzędzie ma nacechowanie klasowe: język mieszkańców przedmieść, środowisk zmarginalizowanych społecznie i subkultur przestępczych. Ten efekt osiągnięty jest głównie środkami leksykalnymi, którym towarzyszy nieciągła narracja, ocierająca się o niepoprawność - a miejscami w istocie okraszona błędami językowymi (głównie składniowymi). W przekładach polskich dominują środki leksykalne, za pierwowzorem penetrujące język w dól, w stronę odmian mówionych, nieoficjalnych, kolokwialnych i nacechowanych ekspresywnie i środowiskowo. Natomiast inne środki obcości kulturowej wyrażanej poprzez język są dość ograniczone - nie sięgają do faktycznych zasobów obcych akcentów i błędów wynikających z różnych doświadczeń struktury rodzimego języka. Może to zbyt pochopna teza, jednak wygląda na to, że literatura polska oswoiła już język blokowisk (casus Masłowska), nie ma jednak jeszcze zdefiniowanego swojego Obcego. Być może dlatego, że to Polak emigrant zawsze gdzieś był Obcym i tej obcości mógł dawać artystyczny wyraz.

\section{Bibliografia}

Balbus, Stanisław ([1996] 2006) Między stylami. Wyd. 2. Kraków: Universitas.

Grochowski, Maciej (2001) Stownik polskich przeklenstw i wulgaryzmów. Warszawa: Państwowe Wydawnictwo Naukowe.

Kowalewska, Aleksandra (2005) „Problematyka przekładu stylu literackiego”. [W:] Krzysztof Hejwowski (red.) Kulturowe i językowe źródła nieprzekładalności. Olecko: Wszechnica Mazurska; 167-177. 
Lapidus, Jens ([2006] 2009) Snabba cash. Wyd. 3. Stockholm: Månpocket.

Lapidus, Jens (2008) Aldrig fucka upp. Stockholm: Månpocket.

Lapidus, Jens ([2006] 2008) Szybki cash. [Snabba cash. Stockholm: Månpocket] (tłum.) Mariusz Kalinowski. Warszawa: WAB.

Lapidus, Jens ([2008] 2009) Zimna stal. [Aldrig fucka upp. Stockholm: Månpocket] (thum.) Mariusz Kalinowski. Warszawa: WAB.

Lapidus, Jens ([2011] 2012) Livet det luxe. Stockholm: Månpocket.

Lapidus, Jens ([2011] 2013) Życie de luxe. [Livet de luxe. Stockholm: Månpocket] (thum.) Paulina Jankowska. Warszawa: WAB.

Markiewicz, Henryk ([1984] 1996) Wymiary dzieła literackiego. Kraków: Universitas.

Mayenowa, Maria R. ([1974] 2000) Poetyka teoretyczna. Wyd. 3. Wrocław: Ossolineum.

Said, Edward W. ([1978] 1991) „Orientalizm. Wprowadzenie”. [W:] Edward Wadie Said Orientalizm. [Orientalism. New York: Pantheon Books] (tłum.) Witold Kalinowski. Warszawa: Państwowy Instytut Wydawniczy; 23-57.

Skudrzykowa, Aldona (1994) Język (za)pisany. O kolokwialności dialogów współczesnej prozy polskiej. Katowice: Wydawnictwo Uniwersytetu Śląskiego.

Stasiak-Górna, Marta (2014) „O tłumaczeniu leksyki potocznej w dialogach literackich na przykładzie szwedzkich kryminałów i ich polskich przekładów”. [W:] Joanna DybiecGajer, Anna Tereszkiewicz (red.) Słowo - kontekst - przekład. Kraków: Tertium; 219227.

Warchala, Jacek (2003) Kategoria potoczności w języku. Katowice: Wydawnictwo Uniwersytetu Śląskiego. 